\title{
Environmental challenges to adopt climate-smart agriculture for cereals cultivated in the South Eastern Pampas of Argentina
}

\author{
Volume 2 Issue 7 - 2017
}

\section{Opinion}

Climate Change has triggered environmental signals that are every year more consistent, evolving dramatic changes in the environment worldwide such as increase of the global mean annual temperature, reduction in snow and ice glaciers, rise in the sea level and occurrence of droughts, floods and heat waves. ${ }^{1}$ Agricultural production has been affected in many ways by these signals through shortening of the growing seasons and yield losses by droughts or floods, revealing a threat to food security at local, regional and global scale. ${ }^{2}$ The agricultural system will face profound environmental challenges due to climate change, having to adapt to changing weather patterns and contribute towards greenhouse gases (GHG) emission reductions. ${ }^{3}$

Among the environmental challenges to face, we must take into account:

1. To address start, duration and end of cereal growing seasons resulting from Climate Change; ${ }^{4}$

2. To adopt agricultural practices to face hydric excess and drought periods and

\section{To decrease the level of agricultural GHG emissions. ${ }^{3}$}

The approach of Climate-Smart Agriculture ${ }^{5,6}$ seems to be the key response to these challenges, through the enhancing of agricultural productivity, the adaptation to Climate Change and the mitigation of its effects by reduction of greenhouse gases (GHG) emissions.

Agricultural productivity has increased in Argentina, with cereals yield going from 1.4 to 4.8 tonnes grain ha-1 during the period 19612014. ${ }^{6}$ However, in the Province of Buenos Aires, cereals production has changed its composition during the period 2006 - 2016, with wheat production decreasing from approx.9 mill. to 5 mill. of tonnes and corn production going from 6.1 to 10.1 mill. Tonnes. ${ }^{7,8}$ The reasons for such change may be found in:

a. changes in the planted area based on market and economics circumstances of agribusiness ${ }^{8,9}$ and

b. An increase of agro climatic vulnerability of the crops, due to a combination of increased climate variability ${ }^{10,11}$ and strong dependence of external inputs. ${ }^{9,12}$

This same pattern replicated in the South Eastern Pampas (SEP), an important region for cereals production in Argentina. The region of SEP is located at the South East of the Buenos Aires Province $\left(37^{\circ}-38.5^{\circ} \mathrm{S}, 57.5^{\circ}-59.5^{\circ} \mathrm{W}\right)$, comprising the parties of Balcarce, General Alvarado, General Pueyrredon, Loberia, Necochea and Tandil (total surface area $=21402 \mathrm{~km}^{2}$ ). Climate of SEP is classified as subhumid-humid mesothermal (Thornwaite, 1948) with a mean annual temperature of $13.9^{\circ} \mathrm{C}$, and a median annual rain of $921 \mathrm{~mm}$. During the period 2001-2016, physical environment of SEP changed

\author{
Cambareri GS \\ Balcarce Research Station, INTA (Instituto Nacional de \\ Tecnologia Agropecuaria), Argentina
}

Correspondence: Cambareri GS, Balcarce Research Station, INTA (Instituto Nacional de Tecnologia Agropecuaria), Km 73.5 RN 226, Balcarce, Buenos Aires, Argentina, Email cambareri.gustavo@inta.gob.ar

Received: October 30, 2017 | Published: December II, 2017

in agreement with Climate Change, since mean annual temperature increased slightly above $1^{\circ} \mathrm{C}$, and annual precipitation median decreased a gross $8 \%$, compared to the period 1971-1986.

Given this environmental change, a climate-smart approach for farmers to cope with thermic and hydric perturbations may include:

a. A new probabilistic calculation for the frost free period;

b. To define planting dates based on daily or decadial probabilities for hydric deficit or excess, ${ }^{13}$ and

c. To select cultivars or hybrids according to the calculated duration of the growing season ${ }^{10,14-16}$ Most of farmers with technical advisoring use to apply such techniques, but a thoroughly revision of practices is needed under the context of Climate Change.

Climate Change also altered the water cycles in SEP, particularly during La Niña events, resulting in hydric excesses for wheat and severe droughts for corn growing seasons, respectively. ${ }^{17}$ For wheat, a revised selection of cultivars according to growth season duration change and hydric excess probability along the year may lead to a climate-smart practice. ${ }^{14}$ For corn, an intelligent strategy from the point of view of CSA would be to "save" water through no-tillage or including cover crops. On one hand, no-tillage has been broadly adopted in Argentina, due mainly to that it offers a simplified management system, very attractive to argentine farmers and to agribusiness $;{ }^{9}$ however, although no-tillage system is carbon-, waterand energy-smart according CSA ${ }^{4,5}$ its effect on GHG emissions maybe not that clear, considering the high volume of residues left in the field and given that crop residues are an important source of GHG emissions in Argentina. ${ }^{5}$ On the other hand, the inclusion of cover crops in a corn rotation is a promising practice for Argentine Pampas due to the ecosystemic services provided to the following crop, mainly through the improvement of soil organic carbon, water infiltration, penetration resistance, and structural stability $;{ }^{18}$ however, no local experiences have been found evaluating cover crops from the point of view of GHG emissions. Thus, the CSA approach offers an opportunity to improve or validate the global perception of 
conservation practices such as no-tillage and cover crops, including GHG emissions in the environmental evaluation.

Agricultural greenhouse gases emissions in Argentina are lower compared to other countries, with a contribution of $2 \%$ to world total agricultural emissions, ${ }^{19}$ but growing in importance. According to the last update of the National Gases Inventory, the agricultural sector contributes with $39 \%$ of emissions to the national total, being agricultural soils a major source with a share of $28.3 \%$ within the agricultural sector total. ${ }^{20}$ Several research projects are seeking to improve emissions database to add robustness to the estimation of agricultural greenhouse gases, backed by agricultural-bound institutions (INTA, Minagro, and agricultural colleges); although, to generate emissions data is costly, so that there is a delay to release data to contrast measured GHG emissions values with the estimations of the IPCC ${ }^{21}$ Tier I methodology. Nonetheless, the latter methodology is a useful tool to contextualize commonly adopted agricultural practices under the CSA framework, particularly for high input demanding crops such as cereals. Overall, SEP mean yields for wheat and corn increased, going from 2.09 and $2.85 \mathrm{t}_{\text {grain }} \mathrm{ha}^{-1}$ during the period 1969-1983 to 4.1 and $6.1 \mathrm{t}$ grain ha ${ }^{-1}$ during 2001-2015, respectively. The annual yield improvement for wheat and corn was sustained by the genetic improvement $\mathrm{t}^{22,23}$ but also by a high consumption of synthetic $\mathrm{N}$-fertilizers, ${ }^{12}$ mainly urea $(46 \% \mathrm{~N})$. In terms of GHG emissions (mainly $\mathrm{N}_{2} \mathrm{O}$ emissions), these additional tonnes of grain meant to emit at least 456 and $539 \mathrm{~kg} \mathrm{CO}_{2}$ eq $^{-1} \mathrm{yr}^{-1}$ to attain yield values around those of the regional means, assuming (i) mean $\mathrm{N}$ rates of 154 and $182 \mathrm{~kg} \mathrm{~N}^{-1}$ for wheat and corn, (ii) an $\mathrm{N}_{2} \mathrm{O}$ emission factor $=1 \%$, and (iii) a global warming potential $=296$ for $\mathrm{N}_{2} \mathrm{O}$ emitted from fertilizers. ${ }^{21}$ However, emissions may be two-fold in wheat if the emission factor calculated by Piccone et al. is applied for the SEP region. This disagreement regarding GHG emissions reveals the need to count with robust regional or zonal emission factors. ${ }^{24}$

The data and indicators mentioned above suggest that a revision is needed for the cereals agricultural systems in SEP under the framework of CSA, considering the environmental challenges already mentioned. To conduct such revision will take an effort in both the analytical and the practical field. Analyses of agricultural systems of SEP will require a profound understanding of temperature and precipitation new trends, and how these variables couple with crop phenology requirements. For the practical field, conservation perceived practices such as no-tillage and cover crops need to be experimentally evaluated since the point of view of GHG emissions in the SEP environment. Finally, studies contrasting measured emission factors against IPCC Tier I (2006) methodology are needed, with a robustness based on more gas sampling dates per year.

\section{Acknowledgements}

The article was written under the framework of the national project: "Greenhouse gases emisions" (code PNNAT 1128023), funded by Instituto Nacional de Tecnologia Agropecuaria (INTA, Argentina).

\section{Conflicts of interests}

The authors declare that there is no conflict of interest.

\section{Funding}

None.

\section{References}

1. Hartmann D, Klein Tank A, Rusticucci M, et al. Observations
Atmosphere and Surface. In: Climate Change 2013: The Physical Science Basis. Contribution of Working Group I to the Fifth Assessment Report of the Intergovernmental Panel on Climate Change [Stocker TF, D Qin, GK Plattner, et al. editors. Cambridge University Press, Cambridge, United Kingdom and New York, NY, USA; 2013.

2. IPCC. Climate Change 2014: Impacts, Adaptation, and Vulnerability. Part A:Global and Sectoral Aspects. Contribution of Working Group II to the Fifth Assessment Report of the Intergovernmental Panel on Climate Change [Field CB, VR Barros, DJ Dokken, et al., editors]. Cambridge University Press, Cambridge, United Kingdom and New York, NY, USA; 2014. 1132 p.

3. Lipper L, Thornton P, Campbell B, et al. Nature Climate Change. 2014;4(12):1068-1072.

4. Kunkel K, Easterling D, Hubbard K, et al. Temporal variations in frost-free season in the United States:1895-2000. Geophys Res Lett. 2004;31:L03201.

5. Climatesmart Agriculture. Source book.

6. Food and Agriculture Organization. Module 1:Why Climate-smart agriculture, forestry and fisheries. In:Climate Smart Agriculture. Source Book. 2013

7. Minagro 2017. Estimaciones Agrícolas.

8. Bolsa de Cereales. Número estadístico 2015/2016. 2017. 95 p.

9. Senesi SI, Daziano MF, Chaddad FR, et al. Ownership versus management: the role of farming networks in Argentina. International Food and Agribusiness Management Review. 2017;20(2):221-238.

10. Irigoyen A, Della Maggiora A, Rizzalli R, et al. Planning the growing season for maize based on climatic variability. II. Relative evapotranspiration and yield. VCongresso Brasileiro de Biometeorologia Piracicaba (Br.). 2011a. 5 p.

11. Magrin G, Travasso MI, Rodriguez G. Climate impacts and adaptation measures of the productive system. In: Soils, agricultural production and climate change.. Avances en la Argentina. Medina CP, Zubillaga M \& Taboada MA, editors. CABA: Ministry of Agriculture and Fisheries of the Nation. 2014.

12. Melgar Y, Torres Duggan M. The fertilizer market in Argentina and its relationship with the agricultural sector. In:Echeverria H\& Garcia F, editors. Fertility of Soils and Fertilization of Crops. Ediciones INTA, Buenos Aires, Argentina; 2015. p. 801-813.

13. Della Maggiora A, Irigoyen A, Gardiol J, et al. Evaluación de un balance de agua en el suelo para maíz. Rev Arg de Agrometeorologia. 2003;2(2):167-176.

14. Sadras VO, Monzon JP. Modelled wheat phenology captures rising temperature trends:Shortened time to flowering and maturity in Australia and Argentina. Field crops research. 2006;99(2):136-146.

15. Irigoyen A, Rizzalli R, Della Maggiora A, et al. Seasonal growing degree-days and predicted phenology of maize at Southern Buenos Aires Province (Argentine). V Congresso Brasileiro de Biometeorologia Piracicaba (Br.). 2011b. p. 5.

16. Irigoyen AI, Della Maggiora AI, Angelocci LR. Planning the growing season for maize based on climatic variability. I. Soil water balance. $V$ Congresso Brasileiro de Biometeorologia Piracicaba (Br.). 2011c. p. 5.

17. Magrin G, Travasso MI, Rodriguez G. Climate impacts and adaptation measures of the productive system. In:Soils, agricultural production and climate change.. Avances en la Argentina. Medina CP, Zubillaga M \& Taboada MA, editors. CABA: Ministry of Agriculture and Fisheries of the Nation. 2014.

18. Rimski-Korsakov E, Alvarez C, Lavado R. Cover crops in the agricultural systems of the Argentine Pampas. J Soil Water Conserv. 2015;70(6):134-140. 
19. Maraseni TN, Qu J. An international comparison of agricultural nitrous oxide emissions. Journal of Cleaner Production. 2016;135:1256-1266.

20. May DS. Inventario de Gases de Efecto Invernadero de Argentina. Ministerio de Ambiente y Desarrollo Sustentable. 2017.

21. IPCC. Guidelines for National Greenhouse Gas Inventories, Prepared by the National Greenhouse Gas Inventories Programme, Eggleston HS, Buendia L, Miwa K, et al. editors. Published: IGES, Japan;2006.

22. Miralles DJ, González FG. Wheat In Argentina: Ecophysiological perspectives of the past, present and future to increase performance. 2010 .
23. Echarte L, Nagore L, Di Matteo J, et al. Grain yield determination and resource use efficiency in maize hybrids released in different decades. In:Agricultural Chemistry. Prof. Margarita Stoytcheva, editor. Argentina; 2013.

24. Thornthwaite CW. An approach toward a rational classification of climate. Geographical review. 1948;38(1):55-94 